\section{DIGITAL COMMONS \\ @ UNIVERSITY OF SOUTH FLORIDA}

\section{ABO: Interactive Journal for Women in the Arts, 1640-1830}

Volume 1

Issue 1 Volume 1 (2011): Women's Poetry

Article 9

2011

\title{
Collecting Women: Poetry and Lives, $1700-1780$ by Chantel M. Lavoie
}

Holly Faith Nelson

Trinity Western University, holly.nelson@twu.ca

Follow this and additional works at: https://digitalcommons.usf.edu/abo

Part of the Dramatic Literature, Criticism and Theory Commons, Educational Methods Commons, Feminist, Gender, and Sexuality Studies Commons, and the Literature in English, British Isles Commons

\section{Recommended Citation}

Nelson, Holly Faith (2011) "Collecting Women: Poetry and Lives, $1700-1780$ by Chantel M. Lavoie," ABO: Interactive Journal for Women in the Arts, 1640-1830: Vol.1: Iss.1, Article 9.

http://dx.doi.org/10.5038/2157-7129.1.1.8

Available at: https://digitalcommons.usf.edu/abo/vol1/iss1/9

This Reviews is brought to you for free and open access by Digital Commons @ University of South Florida. It has been accepted for inclusion in ABO: Interactive Journal for Women in the Arts, 1640-1830 by an authorized administrator of Digital Commons @ University of South Florida. For more information, please contact digitalcommons@usf.edu. 


\section{Collecting Women: Poetry and Lives, $1700-1780$ by Chantel M. Lavoie}

\section{Keywords}

Alexander Pope, Anne Finch, Aphra Behn, biography, Bonnell Thornton, collections, Elizabeth Singer Rowe, gender, George Colman, Katherine Philips, women's poetry

\section{Creative Commons License}

(c) (1) $\odot$

This work is licensed under a Creative Commons Attribution-No Derivative Works 3.0 License. 
Chantel M. Lavoie. Collecting Women: Poetry and Lives, 1700-1780. Lewisburg: Bucknell UP, 2009. \$53.00. 215pp. ISBN 978-0838757499.

Reviewed by Holly Faith Nelson, Trinity Western University

In her slim but significant and richly suggestive volume Collecting Women: Poetry and Lives, 1700-1780, Chantel M. Lavoie traces and theorizes the afterlives of early-modern women writers and their works in eighteenth-century "miscellanies, anthologies, and collective biographies" (33). Building on the research of Barbara Benedict and Laura Mandell, among others, Lavoie attends most closely to the intersection and reciprocal play of women's lives and poems in one or more collections. Throughout the book, Lavoie insists on the "hand-in-glove" relationship between the "biographic and poetic collection," stressing the "high level of hybridization" of the two genres despite the "different artifacts of a knowledge economy" associated with each (31). She, like Benedict, further maintains that the miscellany and anthology are not wholly distinct forms, since a number of collections in the period trouble the boundaries between these genres. As she examines the place of women in these hybrid cultural forms, Lavoie asks us to consider whether their male compilers and editors merely sought to compliment female writers or, alternatively and more radically, to construct a canon of female poets that would complement that of their male counterparts.

Lavoie begins by assessing the difficulties faced by men intent on collecting women's lives and/or poems in eighteenth-century Britain. These compilers and editors, she argues, not only had to assign authority to the women poets in their volumes, but also had to demonstrate their own authority over female versifiers. Collectors and editors also had to combat contemporary criticism of the genre of the poetic miscellany which was sometimes characterized as haphazard and uneven. Since women's poetry was deemed inferior by some of the literary elite, its presence in miscellanies threatened to further debase that genre. Lavoie suggests that the difficulties and tensions inherent in producing miscellanies or anthologies comprised of women writers profoundly impacted how compilers chose to represent these women and their works. However, as Lavoie reminds us, the representation of women in these works was not only shaped by the motives of compilers, but also by the "values and tastes" of the literary marketplace in which the collections were produced and sold (33).

Collecting Women not only undertakes to examine specific collections, most notably Poems by Eminent Ladies and The Virgin Muse, it also narrows its focus to the eighteenth-century compilation of the lives and poems of Elizabeth Singer Rowe, Katherine Philips, and Aphra Behn and to the literary exchange of Alexander Pope and Anne Finch, Countess of Winchilsea. In her chapter on Rowe, Lavoie attends to the aesthetic and moral positioning of Rowe in volumes dedicated solely to her life and writings as well as those in which she is one figure among many. Lavoie dwells on what is privileged in, and omitted from, collections of Rowe's works produced by John Dunton, Edmund Curll, and Theophilus Rowe, establishing connections between the motivations of each compiler - whether literary, spiritual, political, romantic, and/or commercial - and their distinct treatment of Rowe's mutually informative life and writings. 
Lavoie then turns to George Colman and Bonnell Thornton's Poems by Eminent Ladies, the first "substantial printed collection of verse... devoted exclusively to poetry by women," which features the four women poets that lie at the heart of Collecting Women (55). Though, as she earlier claimed, biographical and poetic collections often inform each other, Lavoie credibly argues that this collection is a unique compilatory project in that it is at once a "verse miscellany, anthology, and biographical dictionary," one that democratizes the material it includes through the alphabetical arrangement of its contents (55). Lavoie maps out the collection's indebtedness to George Ballard's Memoirs of Several Ladies of Great Britain and John Duncombe's Feminiad before assessing significant compilatory and editorial choices made by Colman and Thornton. These include the editors informing the reader that most of the women represented in the volume are uneducated, hence the exclusion of what they deem inferior poems, and their privileging of "light and amusing verse over religious and more serious writings," hence the emphasis on satire rather than sensibility (62).

Lavoie also discusses Colman and Thornton's production of an interpretive lens through which to read the women poets and their work. This they accomplish through prefatory comments, biographical introductions and the occasional note. In this paratextual matter, connections between the women writers and celebrated male poets are, on occasion, established to further authorize the women writers and to encourage readers to call to mind the literary works of men like Swift and Pope as they read Poems by Eminent Ladies. Lavoie notes that while this method more firmly established the "literary legacy left by the deceased males," it was the deaths in 1744 and 1745 of Pope and Swift respectively that opened up more space for seventeenth- and eighteenth-century women's poetry in the literary marketplace (60). Lavoie concludes that Poems by Eminent Ladies points to both the "evolution of women's writing" (67) and the ability to market a volume in which women poets - identified in the Preface as an "honour to their sex" and "to their native country" (qtd. in 70) - are the "primary attraction" (69).

In her close readings of the place of Katherine Philips and Aphra Behn in collections published between 1700 and 1780, Lavoie identifies historical and political forces that impact the nature of their appearance in miscellanies and anthologies. She focuses on the didactic use of Philips in The Virgin Muse, a collection of poems produced by the teacher and school administrator James Greenwood. Lavoie claims that Greenwood included four poems by Philips in The Virgin Muse, opening his educational compilation with her poem "The Virgin," in order to improve his "target audience": young females (80). Greenwood presents Philips less as a gifted writer than as the "muse-of-the-miscellany" and a "model" through whom he can teach those readers "skillful and virtuous poetry and behavior" $(16,80)$. In this context, the innocent and matchless Orinda, as with the other male and female poets in the volume, inform and illumine, without polluting, the reader (91). To achieve his objective, Lavoie avers, Greenwood omits Philips's better known friendship poems in favor of her more philosophical verse - "Against Pleasure," "Country Life," and "Death" - which endorse retreating from the world and the worldly, hinting at the need to abjure fame and to keep one's good reputation intact. Although Lavoie does not consider Philips's original deployment of the discourse of retreat as a royalist political stratagem during the Interregnum, we can assume that this discourse is stripped of its earlier political meaning in a "didactic compilation" intent on producing cultured, but innocent and virtuous, young women (79). 
In her absorbing chapter on the place of Aphra Behn in Colman and Thornton's Poems by Eminent Ladies, Lavoie surmises that legal and political circumstances in England between 1753 and 1755 led to the exclusion of four lines in Behn's "The Golden Age" and to the inclusion of "Song to a Scotish tune" and "Sylvio's Complaint. A Song." In a volume that carefully reproduces source texts, the exclusion of the following lines from sections 4 and 7 of "The Golden Age" can only be considered "idiosyncratic" according to Lavoie (98):

Kings that made Laws, first broke 'em, and the Gods

By teaching us Religion first, first set the World at Odds:

Not kept in fear of Gods, no fond Religious cause,

Nor in Obedience to the duller Laws. (Behn, qtd. in 100-01)

Lavoie claims that Colman and Thornton excised the latter two lines (which refer to the past freedom of lovers to meet and unite at will) because they might be seen to challenge Lord Hardwicke's Marriage Act (1753). This Act held that a wedding was only lawful if it took place in a parish church after banns had been published, with few exceptions. Lavoie believes that the former two lines, which censure "hypocritical kings," might cause readers to doubt the Hanoverian monarch in the context of Jacobite risings in the not too distant past (104). Though Behn was a Restoration royalist, and thus a monarchist, she was also an ally of the Stuarts; thus, the couplet in question might have been seen in 1755 to question the legitimacy of the current monarch, George II. Lavoie asserts that to stress the illegitimacy of those who seek to "usurp" the throne of King George, Colman and Thornton included the two Scottish songs, which might appear in 1755 to censure "foolhardy and ambitious lads" like Charles Stuart, The Young Pretender (108). Lavoie argues that it is not insignificant that Hardwicke also "presided as lord high steward at the trials of the rebel Jacobite lords and was primarily responsible for subsequent legislative measures aimed at the Scottish pacification" (110). Since Colman was a student at Lincoln's Inn, where Lord Chancellor Hardwicke was an influential figure, Lavoie infers that all of these editorial choices may stem from a desire not to offend Hardwicke.

In the final chapter of Collecting Women, Lavoie takes up Pope's "To Lady Winchelsea, Occasion'd by some Verses in the Rape of the Lock" and Finch's "Answer to the Foregoing Verses," a poetic dialogue that often appeared as a set in eighteenth-century collections. Lavoie notes that Finch's "The Spleen," which initially appeared in Charles Gildon's Miscellany of Poems by Several Hands, was frequently published in the period alongside "the versified banter of an exchange" in which Finch takes Pope to task over his treatment of "Female Wit" in The Rape of the Lock (121). Lavoie considers Pope's own editing of Finch's "Answer" in his Miscellany Poems on Several Occasions, notably his exclusion of stanza six, in which Finch provides "gory details of Orpheus's skull" rolling "along the Hebrus" (124). This editorial decision, Lavoie suggests, may reflect the different ways in which male and female poets treated the classical myth of Orpheus and Eurydice. After all, as Lavoie notes, Finch transforms Orpheus from a "tragic hero" to a "fool" in her "Answer," and when her poem appeared in Poems by Eminent Ladies, readers would have found that it resonated with sentiments expressed in Mary Monck's "Orpheus and Eurydice" (127). For Lavoie, the insertion of Pope's verse letter and Finch's reply at the conclusion of Poems by Eminent Ladies means that a woman poet has "the 
last word," defending "the entire body of women writers" (virtually all of whom Pope casts aside), and "putting Alexander in his place" (131).

Collecting Women is a well-researched, perceptive, and fascinating study of the assembly and recontextualization of early-modern women's lives and writings in eighteenth-century miscellanies, anthologies, and biographical collections. This is not to say that aspects of Collecting Women could not be strengthened. At times, the reader is distracted by the miscellaneous nature of the monograph itself. Chapters have an atypical number of subdivisions which can make for a rather choppy read, though Lavoie may have intended the book's form to mirror its content. More information on how the treatment of women's poems and lives in English collections published between 1700 and 1780 differs from that in earlier manuscript and print miscellanies might also have led to a more nuanced discussion of the subject. However, any flaws in Collecting Women are vastly outweighed by its merits, and it makes an important contribution to ongoing scholarly dialogues on canon formation, literary history, gender studies, the history of editing, reception theory, and cultural studies. 